\title{
SOLAR PHOTOCATALYTIC EFFICIENCY OF ZINC OXIDE FOR WATER DECONTAMINATION
}

\author{
FARAH EILYANA MOHAMED AND WAN RAFIZAH WAN ABDULLAH ${ }^{\mathrm{B}, *}$
}

School of Ocean Engineering, Universiti Malaysia Terengganu, 21030 Kuala Nerus, Terengganu, Malaysia

${ }^{*}$ Corresponding author: wanrafizah@umt.edu.my

\begin{abstract}
Solar photocatalysis is a green technology that takes advantage of sustainable solar energy for enhancing oxidation process of numerous harmful water contaminants. In this study, a custom solar driven zinc oxide $(\mathrm{ZnO})$-mediated photocatalytic system was developed and its efficiency to remove organic contaminants as well as to disinfect selected bacteria was investigated. Methylene blue (MB) dye was used as the model organic contaminant, while Escherichia coli (E.coli) was used as the model fecal coliform bacteria in contaminated water. A series of photodegradation experiments were conducted on water contaminated with either $10 \mathrm{mg} / \mathrm{L}$ of $\mathrm{MB}$ or $\sim 10^{10} \mathrm{CFU} / \mathrm{ml}$ of E.coli. The experiments were completed under sunlight irradiation in the presence of $1 \mathrm{~g} / \mathrm{L}$ of nano $\mathrm{ZnO}$ photocatalyst for up to 6 hours. Using a solar thermal collector, the photoreactor operated in the temperature range of 25 to $50{ }^{\circ} \mathrm{C}$. The findings revealed that the combination of solar thermal with solar photocatalysis using $\mathrm{ZnO}$ intensified the degradation of $\mathrm{MB}$ and disinfection of E.coli. $98.08 \%$ of MB dye and $99.99 \%$ of E.coli were successfully removed from the water within the first 3 hours of treatment. Almost complete removal was eventually achieved after 6 hours of treatment. It is therefore suggested that $\mathrm{ZnO}$-based solar photocatalytic system developed in this study is highly efficient at enhancing water decontamination process.
\end{abstract}

Keywords: Undergraduate research, zinc oxide, photocatalyst, solar thermal, water purification

\section{Introduction}

Malaysia is a tropical country that is located in the equatorial zone. Therefore, it receives an average daily solar radiation of $4500 \mathrm{kWh} / \mathrm{m}^{2}$ and abundant sunlight for almost 12 hours per day (Aziz et al., 2016). Apart from the sunlight, at least $70 \%$ of the solar energy is available as heat. The renewable source of energy from the sun can be potentially utilized for enhancement of existing photocatalytic process for water purification.

The heterogeneous solar photocatalytic process utilizes the ultraviolet-visible light in solar spectrum to photoexcite a semiconductor catalyst in the presence of oxygen (Malato et al., 2016). Various highly oxidizing free reactive oxygen species (ROS) including hydroxyl $(\bullet \mathrm{OH})$ and superoxide $\left(\cdot \mathrm{O}_{2}{ }^{-}\right)$radicals generated from the process will effectively oxidize the organic and microbiological contaminants in aqueous solution (Kondrakov et al., 2016). Solar photocatalysis process using $\mathrm{ZnO}, \mathrm{TiO}_{2}$ and their derivatives have been extensively reported for decontamination of water from various types of contaminants such as synthetic dyes, natural organic matter, surfactants, pesticides and pharmaceuticals (Rajendran et al., 2016; Malato et al., 2016; Ljubas 2005; Hussein, 2012). Small number of studies have also been conducted to investigate the use of lab-synthesized photocatalyst material for solar disinfection of waterborne bacteria and fungus (Mac Mahon et al., 2017; Das et al., 2017; Rodrigues-Silva et al., 2017).

Most of existing works correlate the efficiency of solar photocatalysis to several important factors such as sunlight intensities, solar exposure time and light absorption capacity of the photocatalyst material being used (Byrne et al., 2010; Mahalakshmi et al., 2007; Behnajady et al., 2006). These identified factors are responsible for controlling the photogeneration of ROS during photocatalysis reaction. However very few information is currently available that explains the role of temperature on the solar photocatalysis mechanism. Based on early findings by Lee et al., (2016) and Palmer et al., (2002), the solution temperature where the UV-driven photocatalysis process takes place may influence the interaction between the molecules of contaminant and the catalyst surface. Variation in temperature will also affect the concentration of dissolve oxygen in the treated solution. As result, the photogeneration of ROS could be affected, leading to lower or higher photocatalytic performance. Hence, this study presents the assessment of solar photocatalytic efficiency of $\mathrm{ZnO}$ for decontamination of water from organic and microbiological contaminants. In order to 
elucidate the role of temperature in solar photocatalysis process, the photodegradation of selected model contaminants was performed at elevated operating temperature using a custom solar driven $\mathrm{ZnO}$-mediated photocatalytic system with solar thermal collector.

\section{Materials and Methods Selection of Photocatalyst}

$\mathrm{ZnO}$ nanopowder with the particle size of less than $1 \mu \mathrm{m}$ and the purity of $99 \%$ obtained from Sigma Aldrich was used as the main photocatalyst material. The selection of $\mathrm{ZnO}$ as photocatalyst was driven by its unique characteristics such as direct and wide band gap in the nearUV spectral region, strong oxidation ability, excellent photo activity, and a large free-exciton binding energy (Mondal \& Sharma, 2014). The morphology of the catalyst was examined using the scanning electron microscopy technique (SEM).

\section{Preparation of Synthetic Water Contaminants}

Two model contaminants used in this study were the methylene blue (MB) dye and Escherichia coli (E.coli) bacteria. The $10 \mathrm{mg} / \mathrm{L}$ of $\mathrm{MB}$ solution was prepared by dissolving $\mathrm{MB}$ trihydrate $\left(\mathrm{C}_{16} \mathrm{H}_{18} \mathrm{C} 1 \mathrm{~N}_{3} \mathrm{~S} .3 \mathrm{H}_{2} \mathrm{O}\right)$ with the purity of $95 \%$ in $1 \mathrm{~L}$ of deionized water. In a separate container, $1 \mathrm{~L}$ of water contaminated with $\sim 10^{10} \mathrm{CFU} / \mathrm{ml}$ of bacteria was prepared by diluting a volume of concentrated broth containing $E$. coli into deionized water. The E.coli strain supplied by Microbiology Laboratory, School of Fundamental Science, Universiti Malaysia Terengganu, was grown in the nutrient broth (Merck) for 24 hours at $37^{\circ} \mathrm{C}$.

\section{Assembly of Solar Photoreactor}

Figure 1 shows the set-up for solar photoreactor used for the experiments. Table 1 summarizes the roles of components of a solar photoreactor system.

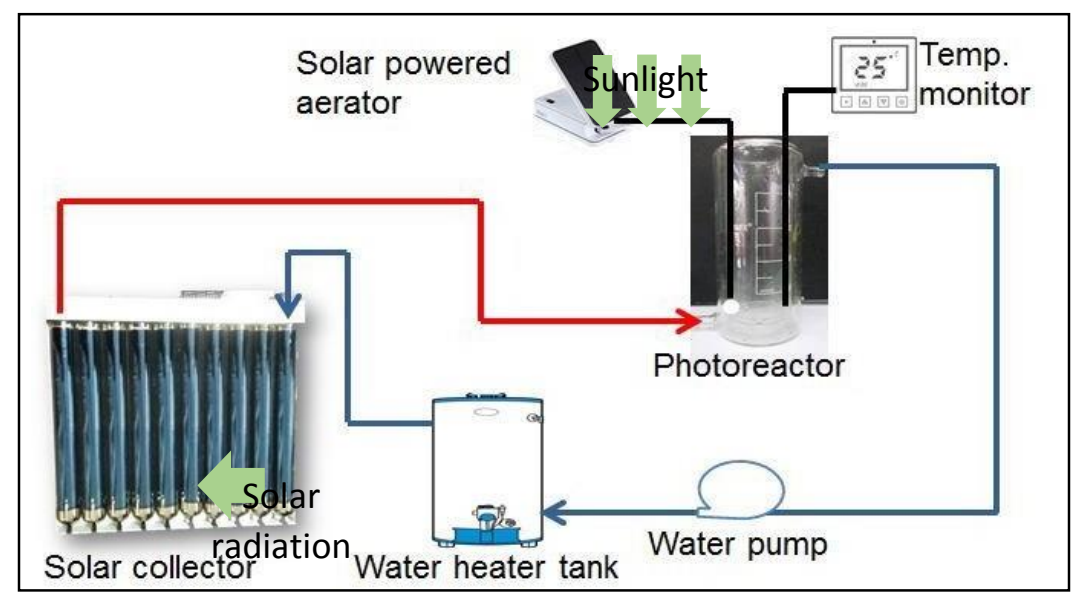

Figure 1. Solar photoreactor set-up with solar thermal collector.

Table 1: Role of components in a solar photoreactor.

\begin{tabular}{ll}
\hline \multicolumn{1}{c}{ Component } & \multicolumn{1}{c}{ Function } \\
\hline Photoreactor & $\begin{array}{l}\text { To contain the mixture of water to be treated and catalyst } \\
\text { during photodegradation reaction. } \\
\text { To mechanically circulate the heating medium (water) from } \\
\text { photoreactor to the solar collector. } \\
\text { Tater pump }\end{array}$ \\
$\begin{array}{l}\text { To store or hold the heated water. } \\
\text { To concentrate the solar radiation for heating the water. } \\
\text { Solar collector }\end{array}$ & $\begin{array}{l}\text { To aerate the mixture in photoreactor with air. } \\
\text { To display temperature in the photoreactor. } \\
\text { Temperature monitor }\end{array}$ \\
Tatalyst & $\begin{array}{l}\text { To increase the rate of reaction for photodegradation process } \\
\text { of contaminant in the presence of light }\end{array}$ \\
\hline
\end{tabular}


The batch photocatalytic process was performed in a photoreactor (a jacket biker) with the volume capacity of 1 $\mathrm{L}$ under direct and natural sunlight. The process was catalyzed by $1 \mathrm{~g} / \mathrm{L}$ of $\mathrm{ZnO}$ photocatalyst while the aeration with air at $12 \mathrm{~L} / \mathrm{min}$ was provided to saturate the treated water with sufficient oxygen and to create turbulence for better mixing of catalyst. The temperature of the mixture in the photoreactor was increased by hot water circulation from a tubular solar collector. The heating profile of the solar collector was monitored using a digital thermometer. It was expected that the elevation of reaction temperature by solar radiation might promote the photodegradation process in the reactor. Solar radiation was also monitored during experiment using a solar power meter (Model SM206).

\section{Solar Photodegradation of MB Dye Solution}

Photodegradation of $10 \mathrm{mg} / \mathrm{L}$ of $\mathrm{MB}$ dye solution was performed in the photoreactor and in the presence of $1 \mathrm{~g} / \mathrm{L}$ of $\mathrm{ZnO}$. A 30-minute treatment in the dark was performed prior to the sunlight exposure in order to achieve adsorption equilibrium. Subsequently, the photoreactor containing the slurry of dye solution and catalyst was run under the sunlight for 6 hours consecutively. In order to maximize the sunlight exposure during experiment, the photoreactor was placed in an open area, away from any shadows from buildings or trees. Figure 2 shows the location of the experimental site in Universiti Malaysia Terengganu, Malaysia (GPS location: $5.4087^{\circ} \mathrm{N}$, $\left.103.0888^{\circ} \mathrm{E}\right)$.

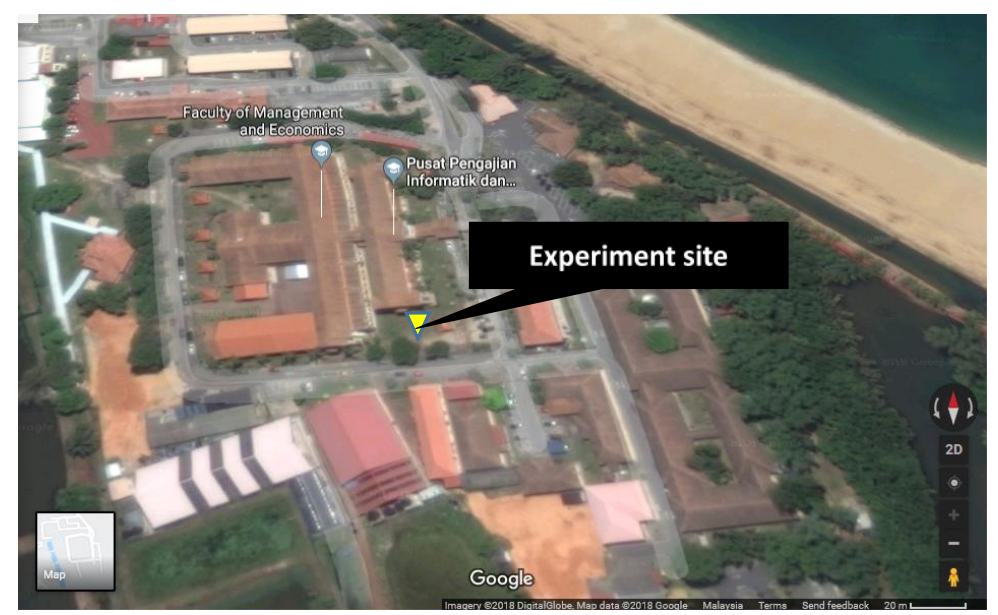

Figure 2: Location of the experiment

Every hour, approximately $5 \mathrm{ml}$ of effluent was withdrawn and centrifuged twice at $4000 \mathrm{rpm}$ to separate the suspended $\mathrm{ZnO}$. The supernant was taken and analysed using UV-visible spectrophotometer (Model UV-1800) to

$$
\text { Photocatalytic efficiency, } \mathrm{R}_{O}(\%)=\frac{\mathrm{A}_{\mathrm{i}}-\mathrm{A}_{\mathrm{f}}}{\mathrm{A}_{\mathrm{i}}} \times 100 \%
$$

where $A_{i}$ is the initial absorbance for $M B$ peak at $665 \mathrm{~nm}$ and $A_{f}$ is the final absorbance for MB peak at $665 \mathrm{~nm}$. A control experiment was also conducted on $10 \mathrm{mg} / \mathrm{L}$ of $\mathrm{MB}$ solution mixed with $1 \mathrm{~g} / \mathrm{L}$ of $\mathrm{ZnO}$. The mixture was

\section{Solar Photocatalytic Inactivation of E. coli}

Photocatalytic inactivation of waterborne bacteria was performed by treating $1 \mathrm{~L}$ solution containing approximately $10^{10} \mathrm{CFU} / \mathrm{ml}$ of $E$. coli under the sunlight in the presence of $1 \mathrm{~g} / \mathrm{L}$ of $\mathrm{ZnO}$ for up to 6 hours. The mixture was aerated with $12 \mathrm{~L} / \mathrm{min}$ of air throughout the treatment. Every hour, $5 \mathrm{ml}$ of effluent was taken and the final concentration of bacteria in the treated effluent was determine the remaining $\mathrm{MB}$ in the solution. The photocatalytic efficiency, $\mathrm{R}_{\mathrm{o}}(\%)$ value was calculated based on the Equation (1).

exposed to direct sunlight for 6 hours without heating by the tubular solar collector.

determined using plate count method. The effluent underwent a serial dilution in saline water to reduce a dense E.coli cells to a more usable concentration. A volume of $0.1 \mathrm{ml}$ of the diluted effluent was transferred into an agar plate and incubated upside-down overnight at $37{ }^{\circ} \mathrm{C}$. The colony was counted using Quebec colony counter and the different numbers of colonies were obtained ranging from 30 to 300 colonies. The calculation of $\mathrm{CFU} / \mathrm{ml}$ was carried out using Equation (2). 


$$
\mathrm{CFU} / \mathrm{ml}=\frac{\text { Number of colony on agar plate } \times \text { Dilution factor }}{\text { Volume plated in } \mathrm{ml}}
$$

The photocatalytic inactivation efficiency, $\mathrm{R}_{\mathrm{B}}$ of $\mathrm{ZnO}$ against E.coli was determined using Equation (3).

$$
\text { Photocatalytic inactivati on efficiency, } \mathrm{R}_{\mathrm{B}}(\%)=\frac{C_{\mathrm{i}}-\mathrm{C}_{\mathrm{f}}}{\mathrm{C}_{\mathrm{i}}} \times 100 \%
$$

where $\mathrm{C}_{\mathrm{i}}$ is the colony forming units of initial solution and $\mathrm{C}_{\mathrm{f}}$ is the colony forming units of treated effluent.

\section{Results and Discussion \\ Operational Reliability of Solar Driven and $\mathrm{ZnO}$ - Mediated Photocatalytic System}

Operational reliability of the custom-made solar photocatalytic system used in this study was evaluated to ensure that every component of the process performed its intended function adequately for specific exposure period.
Above all, the system proposed in this study was designed with the intention of combining solar photocatalytic effect of $\mathrm{ZnO}$ and application of solar thermal to elevate the operating temperature above ambient temperature during photodegradation process. For that reason, the temperature profile of the reactor during 6 hours of sunlight exposure is tabulated in Table 2.

\begin{tabular}{|c|c|c|c|c|c|c|c|c|c|}
\hline \multirow[t]{2}{*}{ Time/Date } & \multicolumn{7}{|c|}{ Temperature $\left({ }^{\circ} \mathrm{C}\right)$} & \multirow[b]{2}{*}{$\begin{array}{l}\text { Avg. } \\
\text { heating } \\
\text { rate per } \\
\text { volume } \\
\left({ }^{\circ} \mathrm{C} / \mathrm{h} . \mathrm{L}\right) \\
\end{array}$} & \multirow{2}{*}{$\begin{array}{c}\mathrm{T} \\
\text { increase } \\
(\%)\end{array}$} \\
\hline & $10 \mathrm{am}$ & $11 \mathrm{am}$ & $12 \mathrm{pm}$ & $1 \mathrm{pm}$ & $2 \mathrm{pm}$ & $3 \mathrm{pm}$ & $4 \mathrm{pm}$ & & \\
\hline $\begin{array}{l}\text { Day 1: } \\
\text { 25/3/2018 } \\
\text { (Mostly sunny) }\end{array}$ & 29.9 & 32.6 & 45.0 & 45.8 & 44.8 & 43.3 & 44.6 & 2.65 & 53.18 \\
\hline $\begin{array}{l}\text { Day 2: } \\
\text { 13/4/2018 } \\
\text { (Partly cloudy) }\end{array}$ & 30.3 & 45.2 & 47.6 & 50.1 & 49.8 & 47.6 & 38.4 & 3.30 & 65.35 \\
\hline $\begin{array}{l}\text { Day 3: } \\
\text { 14/4/2018 } \\
\text { (Mostly sunny) }\end{array}$ & 31.2 & 42.8 & 48.8 & 48.0 & 45.0 & 45.6 & 45.8 & 2.93 & 56.41 \\
\hline $\begin{array}{l}\text { Day 4: } \\
15 / 4 / 2018 \\
\text { (Partly cloudy) }\end{array}$ & 32.2 & 43.7 & 44.9 & 47.8 & 47.3 & 43.2 & 40.3 & 2.60 & 48.45 \\
\hline $\begin{array}{l}\text { Day 5: } \\
\text { 16/4/2018 } \\
\text { (Sunny) }\end{array}$ & 31.6 & 47.5 & 50.1 & 51.9 & 51.3 & 48.9 & 49.9 & 3.38 & 64.24 \\
\hline $\begin{array}{l}\text { Day 6: } \\
\text { 18/4/2018 } \\
\text { (Sunny) } \\
\end{array}$ & 29.9 & 44.9 & 47.6 & 50.1 & 45.1 & 48.4 & 50.0 & 3.37 & 67.56 \\
\hline \multicolumn{10}{|c|}{ Indicator } \\
\hline \multicolumn{10}{|c|}{$\begin{array}{l}\text { Sunny }-0 / 8 \text { opaque clouds } \\
\text { Mostly sunny }-1 / 8-2 / 8 \text { opaque clouds } \\
\text { Partly cloudy }-3 / 8-5 / 8 \text { opaque clouds } \\
\text { Mostly cloudy }-6 / 8-7 / 8 \text { opaque clouds } \\
\text { Cloudy }-8 / 8 \text { opaque clouds }\end{array}$} \\
\hline
\end{tabular}

Table 2: Solar thermal heating profile for 6 days.

Figure 3 shows the hourly temperature variation in photoreactor containing $1 \mathrm{~L}$ of purely water for 6 days. Depending on the sunlight intensity $\left(200-1080 \mathrm{~W} / \mathrm{m}^{2}\right)$, the solar thermal energy harvesting using tubular solar collector was reliable and temperature of the photoreactor could be operated within the temperature range of $30-50$ ${ }^{\circ} \mathrm{C}$. 


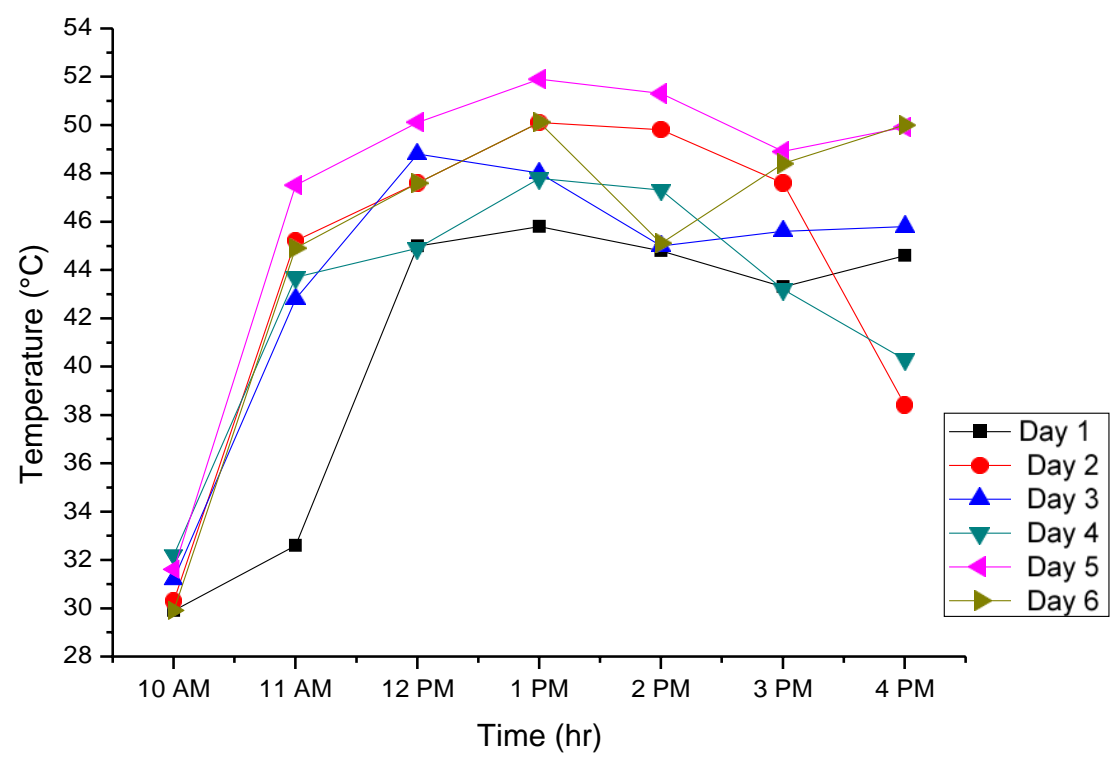

Figure 3: The hourly temperature variation in the photoreactor during 6 hours of sunlight exposure.

Figure 4 shows the SEM image of the $\mathrm{ZnO}$ photocatalyst powder used extensively in the experiment. It can be clearly seen that the $\mathrm{ZnO}$ had the particle size of less than $1 \mu \mathrm{m}$. With the aid of solar aerator, the turbulence created in the photoreactor did not only introduce oxygen but also dispersed $\mathrm{ZnO}$ photocatalyst homogeneously. In addition, the nanoscale particles of $\mathrm{ZnO}$ provided high surface area per volume ratio for excellent sunlight absorption.

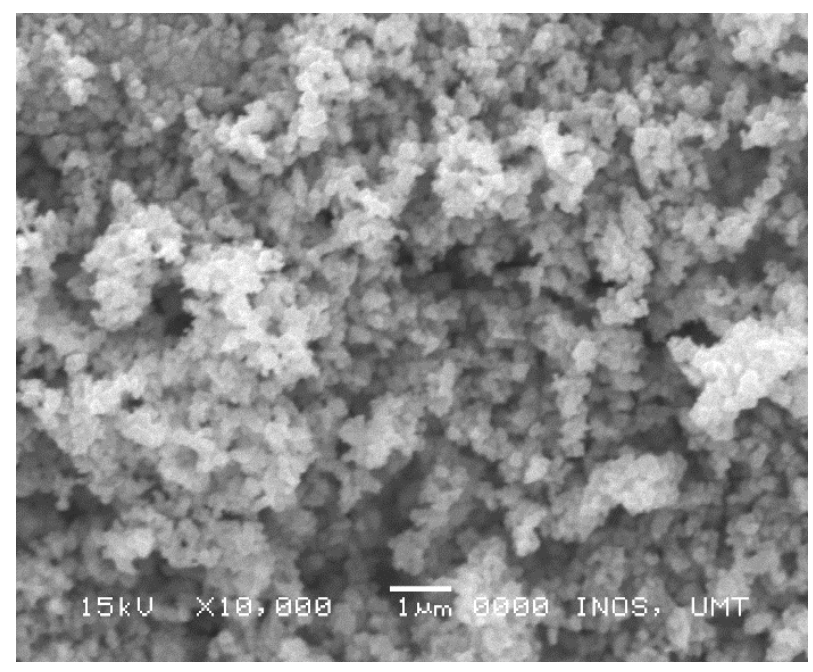

Figure 4: SEM image of $\mathrm{ZnO}$ photocatalyst.

Solar Photocatalytic Performance of $\mathrm{ZnO}$ for Decontamination of Methylene Blue Dye at Elevated Temperature

Photodegradation of $10 \mathrm{mg} / \mathrm{L}$ of MB dye was completed under sunlight exposure for 6 hours consecutively in the presence of $1 \mathrm{~g} / \mathrm{L}$ of $\mathrm{ZnO}$ photocatalyst. Figure 5 shows the changes in UV visible spectra of MB in initial and treated solutions. The maximum absorption peak at the wavelength of $665 \mathrm{~nm}$ indicated the presence of methylene blue compound in the analysed sample. Gradual decrement of this peak with treatment time implies the decomposition of MB molecules by solar photocatalysis process mediated by $\mathrm{ZnO}$. Rapid decolorization of MB dye solution due to photodegradation was observed visibly (refer Figure 6). The photocatalytic efficiency to remove dye (Model 
organic contaminant) $R_{O}$ using the system is listed in Table 3 and the trend is shown in Figure 7.

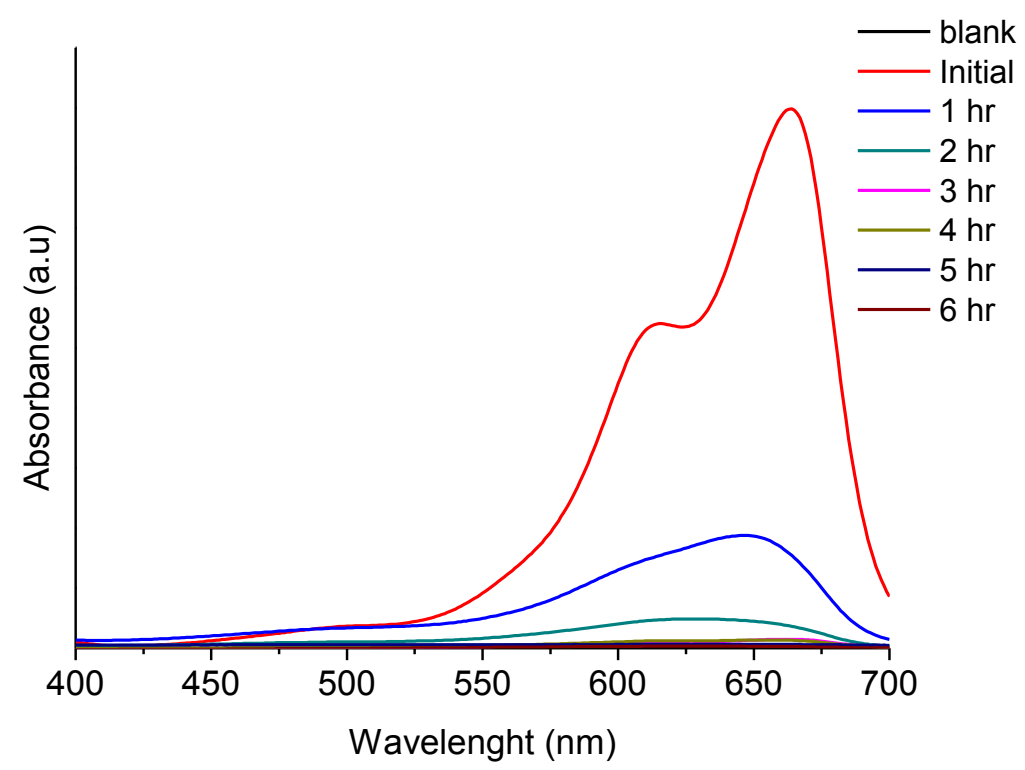

Figure 5: UV-Vis spectra of photodegradation of MB dye under sunlight exposure for 6 hours

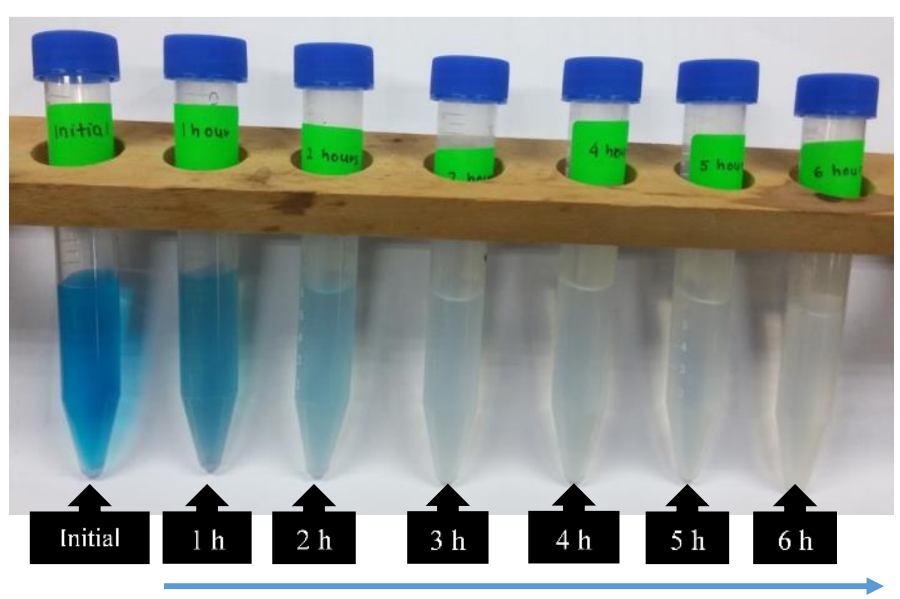

Sunlight exposure time (h)

Figure 6: Decolourization of MB dye solution after solar photodegradation process.

Table 3: Performance of $\mathrm{ZnO}$ solar photocatalysis process for decontamination of $\mathrm{MB}$ dye under sunlight exposure for 6 hours

\begin{tabular}{cccc}
\hline $\begin{array}{c}\text { Time } \\
(\mathbf{h r})\end{array}$ & $\begin{array}{c}\text { Photoreactor temperature } \\
\left({ }^{\circ} \mathbf{C}\right)(\mathbf{\pm 0 . 1})\end{array}$ & Absorbance (nm) & $\begin{array}{c}\text { Photocatalytic efficiency, } \\
\left.\text { Ro }_{\mathbf{\%}} \mathbf{\%}\right)\end{array}$ \\
\hline $\mathbf{0}$ & 30.3 & 2.237 & 0 \\
$\mathbf{1}$ & 45.2 & 0.378 & 83.1 \\
$\mathbf{2}$ & 47.6 & 0.096 & 95.71 \\
$\mathbf{3}$ & 50.1 & 0.043 & 98.08 \\
$\mathbf{4}$ & 49.8 & 0.039 & 98.26 \\
$\mathbf{5}$ & 47.6 & 0.016 & 99.28 \\
$\mathbf{6}$ & 38.4 & 0.007 & 99.69 \\
\hline
\end{tabular}




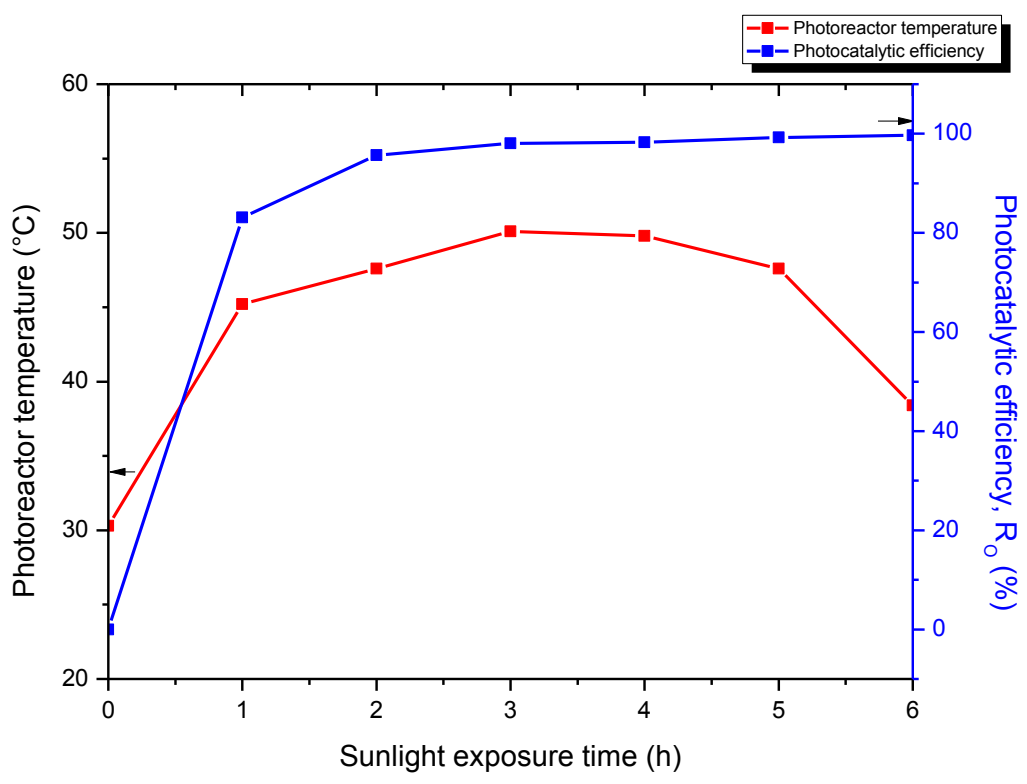

Figure 7: Photocatalytic efficiency, $\mathrm{R}_{\mathrm{o}}$ of $\mathrm{ZnO}$ to remove $\mathrm{MB}$ dye under sunlight exposure for 6 hours.

The photoreactor temperature reached the highest value $\left(\sim 50^{\circ} \mathrm{C}\right)$ within the $3^{\text {rd }}$ to $4^{\text {th }}$ hour of sunlight exposure. The application of tubular solar collector increased the temperature within the reactor by $67 \%$. More than $98 \%$ of $\mathrm{MB}$ dye was successfully removed after the $3^{\text {rd }}$ hour and $99.69 \%$ efficiency was reached after 6 hours of sunlight exposure. The most rapid rate of reaction was observed within the first 1 hour. As comparison, the efficiency of $67.20 \%$ was achieved in the control experiment conducted without solar thermal heating. Even under full sunlight condition, the natural solar radiation could only increase the temperature in the reactor by $16 \%$. This result suggests that synergistic exposure of photocatalyst to sunlight and heat treatment by solar radiation promoted the photogeneration of reactive oxygen species such as $\bullet \mathrm{OH}$ and $\bullet \mathrm{O}_{2}{ }^{-}$radicals on the catalyst surface. These radicals were responsible for oxidizing and destruction of the $\mathrm{MB}$ molecules in the contaminated solution.

\section{Solar Photocatalytic Performance of ZnO for Inactivation of E.coli at Elevated Temperature}

The photodegradation reaction was conducted on $1 \mathrm{~L}$ of water contaminated with $\sim 10^{10} \mathrm{CFU} / \mathrm{ml}$ of Gram negative bacteria E.coli under sunlight irradiation in the presence of $1 \mathrm{~g} / \mathrm{L}$ of $\mathrm{ZnO}$ for up to 6 hours. Solar thermal energy was harvested and applied for elevating the temperature within the photoreactor in the range of 30 to $45{ }^{\circ} \mathrm{C}$. Table 4 and Figure 8 show the hourly performance of solar photocatalysis process mediated by $\mathrm{ZnO}$ for inactivation of $E$. coli bacteria in the contaminated water. Figure 9 shows the rapid decrement in the density of E.coli colony on agar plate during 6 hour sunlight exposure at dilution factor of $10^{-7}$.

Table 4: Performance of $\mathrm{ZnO}$ solar photocatalysis process for inactivation of E.coli under sunlight exposure for 6 hours

\begin{tabular}{cccc}
\hline $\begin{array}{c}\text { Time } \\
(\mathbf{h r})\end{array}$ & $\begin{array}{c}\text { Photoreactor temperature } \\
\left({ }^{\mathbf{0}} \mathbf{C}\right)\end{array}$ & Bacteria count (CFU/ml) & $\begin{array}{c}\text { Photocatalytic inactivation } \\
\text { efficiency, } \mathbf{R}_{\mathbf{B}}(\boldsymbol{\%})\end{array}$ \\
\hline $\mathbf{0}$ & 31.2 & $3.0 \times 10^{10}$ & 0 \\
$\mathbf{1}$ & 42.8 & $2.1 \times 10^{10}$ & 30.0 \\
$\mathbf{2}$ & 48.8 & 0 & 100.0 \\
$\mathbf{3}$ & 48.0 & 0 & 100.0 \\
$\mathbf{4}$ & 45.0 & 0 & 100.0 \\
$\mathbf{5}$ & 45.6 & 0 & 100.0 \\
$\mathbf{6}$ & 45.8 & 0 & 100.0 \\
\hline
\end{tabular}




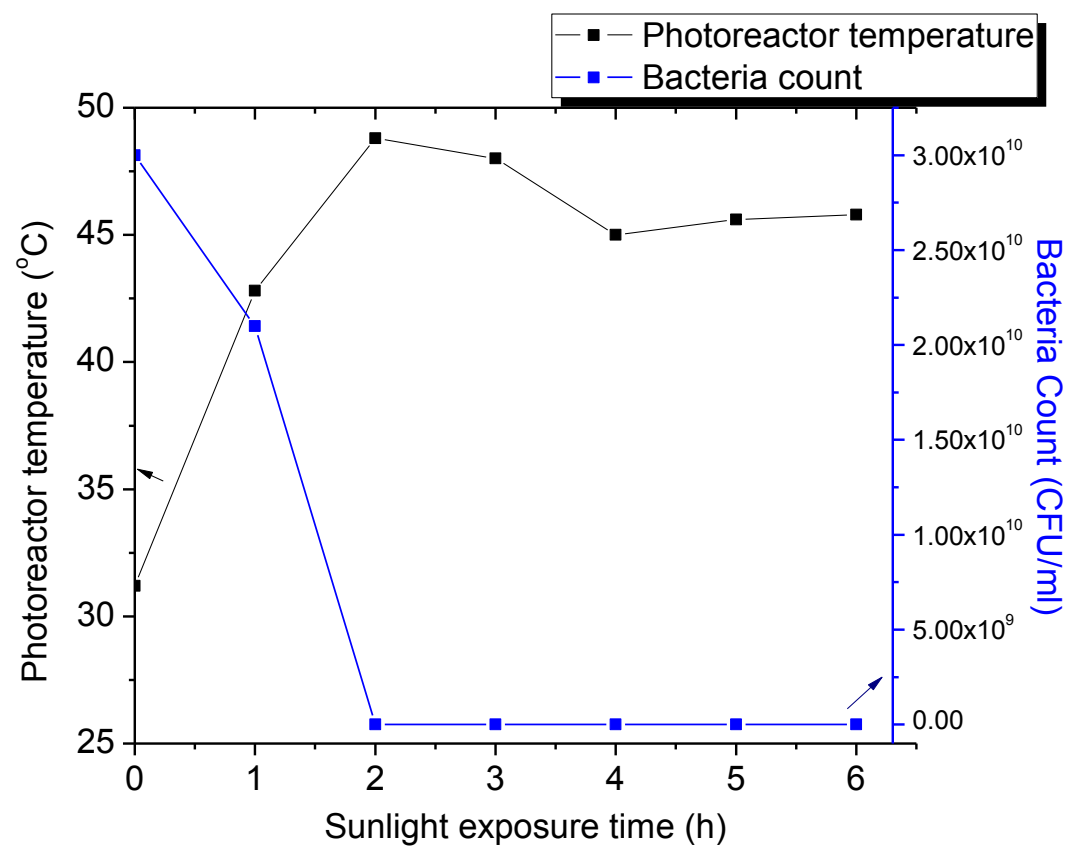

Figure 8: Photocatalytic inactivation performance of $\mathrm{ZnO}$ to remove E.coli under sunlight exposure for 6 hours 


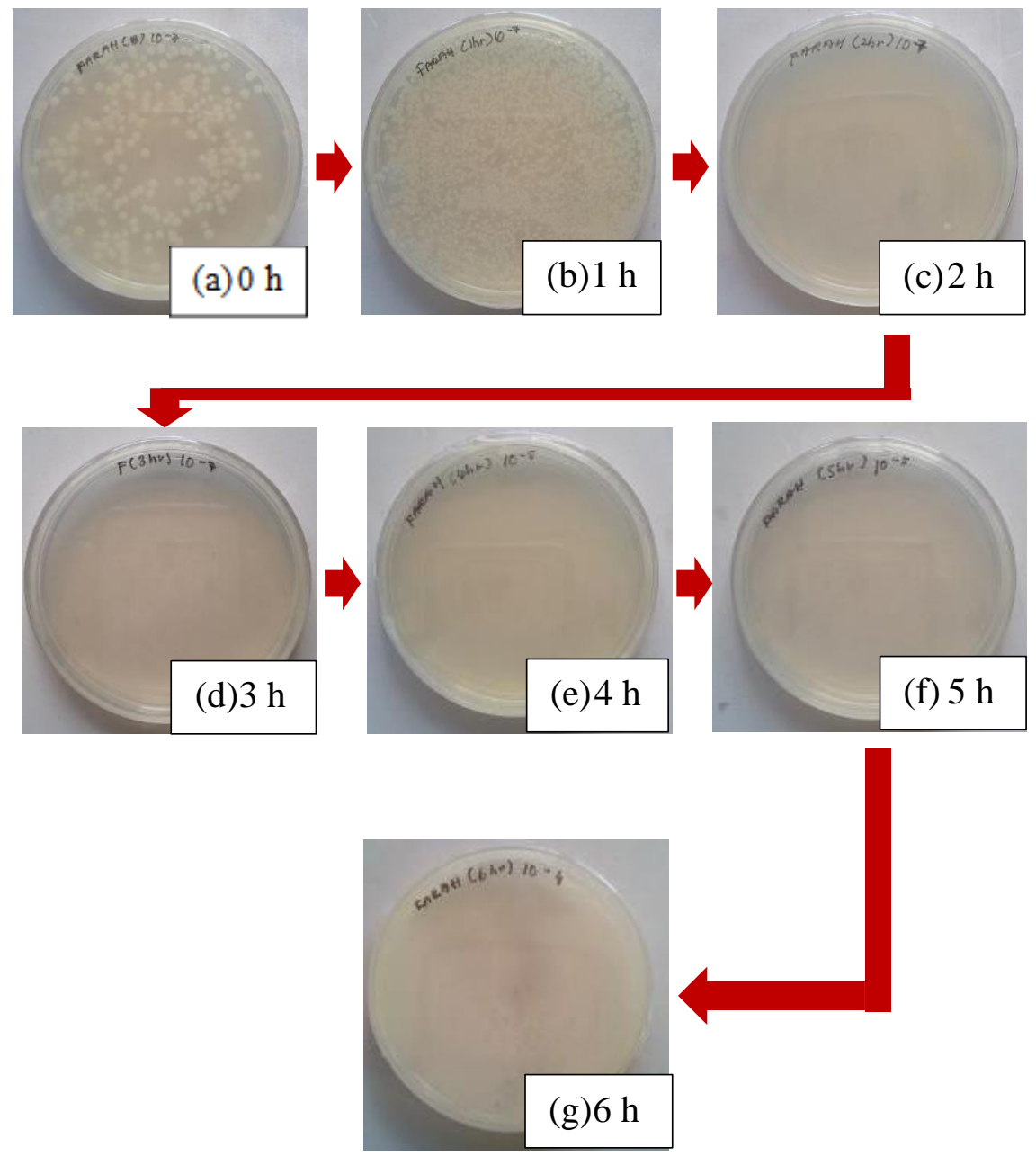

Figure 9: Rapid inactivation and removal of E.coli by using $\mathrm{ZnO}$ solar photocatalysis process at high temperature.

Based on Table 4 and Figure 8, effective inactivation of E.coli bacteria was achieved within the first 2 hours. Complete removal of E.coli from the initially contaminated water was observed as early as the $2^{\text {nd }}$ hour of sunlight exposure when the temperature in the reactor reached approximately $49{ }^{\circ} \mathrm{C}$. Similar to the previous experiment, simultaneous action by $\mathrm{ZnO}$ photocatalyst which encouraged the photogeneration of highly oxidizing radicals and heating by solar thermal energy successfully promoted rapid removal of E.coli. Despite a decline in photoreactor temperature when the sunlight exposure exceeded the second hour, reoccurring of bacteria was unlikely as the bacteria cells were entirely damaged. The photocatalytic inactivation efficiency, $\mathrm{R}_{\mathrm{B}}$ of $\mathrm{ZnO}$ at the end of the process was reaching $100 \%$. In this study, it can be suggested that performing photocatalytic process at high temperature had some major advantages. It is believed that by increasing the operating temperature above the ambient condition, the photogeneration of radicals on $\mathrm{ZnO}$ surface could be accelerated. This is in agreement with Umar and Aziz (2013) which observed the increment in photoactivity of photocatalyst under high temperature condition. Meanwhile, as the photodegradation reaction is a thermal activated process, oxidizing of bacteria cell wall by radical actions multiplied at high temperature. As supported by Malato et al., (2009) and Mai et al., (2016), a Gram negative bacteria like E.coli has thinner cell membrane layer (less than $10 \mathrm{~nm}$ ) and therefore it shows higher sensitivity to high temperature and highly oxidizing $\cdot \mathrm{OH}$ radicals. It is widely accepted that $\bullet \mathrm{OH}$ radicals effectively oxidize the lipid layer in membrane cell wall and the progression of lipid peroxidation causing total damage of bacteria.

\section{Conclusion}

A combination of solar thermal heating and solar photocatalysis process mediated by $\mathrm{ZnO}$ is a sustainable and reliable way to decontaminate water from organic or microbiological contaminants with minimal usage of chemicals. The photoreactor system developed in this study fully utilized solar energy to activate the 
photocatalyst and to accelerate the reaction rate for photodegradation process of water contaminants by increasing the operating temperature to a suitable range. The solar photocatalytic system which incorporated $1 \mathrm{~g} / \mathrm{L}$ of $\mathrm{ZnO}$ nanopowder as catalyst exhibited $99.69 \%$ efficiency to remove MB dye (model organic contaminant) and $100 \%$ efficiency to inactivate E.coli (model microbiological contaminant) under sunlight exposure for 6 hours at operating temperature range of $30-50{ }^{\circ} \mathrm{C}$.

\section{Acknowledgements}

The author would like to acknowledge the financial support received from Universiti Malaysia Terengganu through Tabung Penyelidik Muda (TPM) 68007/2016/75 and School of Ocean Engineering, Universiti Malaysia Terengganu for provision of research facilities and technical support.

\section{References}

Aziz, P. A., Wahid, S. S. A., Arief, Y. Z., \& Aziz, N. A. (2016). Evaluation of Solar Energy Potential in Malaysia. Trends in Bioinformatics, 9(2), 35-43.

Behnajady, M. A., Modirshahla, N., \& Hamzavi, R. (2006). Kinetic study on photocatalytic degradation of CI Acid Yellow 23 by ZnO photocatalyst. Journal of Hazardous Materials, 133(1): 226-232.

Byrne, J. A., Fernandez-Ibañez, P. A., Dunlop, P. S., Alrousan, D. M., Hamilton, J. W., \& Abdel-Mottaleb, M. S. (2010). Photocatalytic enhancement for solar disinfection of water: A review. International Journal of Photoenergy, 2011: 77.

Das, S., Ranjana, N., Misra, A. J., Suar, M., Mishra, A., Tamhankar, A. J., Lundborg, C.S. \& Tripathy, S. K. (2017). Disinfection of the water borne pathogens Escherichia coli and Staphylococcus aureus by Solar Photocatalysis using sonochemically synthesized reusable Ag@ZnO core-shell nanoparticles. International Journal of Environmental Research and Public Health, 14(7), 747.

Hussein, F. H. (2012). Photochemical treatments of textile industries wastewater. Asian Journal of Chemistry, 24(12), 5427.

Kondrakov, A. O., Ignatev, A. N., Lunin, V. V., Frimmel, F. H., Bräse, S., \& Horn, H. (2016). Roles of water and dissolved oxygen in photocatalytic generation of free $\mathrm{OH}$ radicals in aqueous $\mathrm{TiO}_{2}$ suspensions: An isotope labeling study. Applied Catalysis B: Environmental 182, 424-430.
Lee, K. M., Lai, C. W., Ngai, K. S., \& Juan, J. C. (2016). Recent developments of zinc oxide based photocatalyst in water treatment technology: A review. Water Research, 88: 428-448.

Ljubas, D. 2005. Solar photocatalysis - A possible step in drinking water treatment. Energy, 30(10), 1699-1710.

Mac Mahon, J., Pillai, S. C., Kelly, J. M., \& Gill, L. W. (2017). Solar photocatalytic disinfection of E. coli and bacteriophages MS2, $\Phi$ X174 and PR772 using $\mathrm{TiO}_{2}$, $\mathrm{ZnO}$ and ruthenium based complexes in a continuous flow system. Journal of Photochemistry and Photobiology B: Biology, 170, 79-90.

Mahalakshmi, M., Arabindoo, B., Palanichamy, M., \& Murugesan, V. (2007). Photocatalytic degradation of carbofuran using semiconductor oxides. Journal of Hazardous Materials, 143(1): 240-245.

Mai-Prochnow, A., Clauson, M., Hong, J., \& Murphy, A. B. (2016). Gram positive and Gram negative bacteria differ in their sensitivity to cold plasma. Scientific Reports, 6: 38610.

Malato, S., Fernández-Ibáñez, P., Maldonado, M. I., Blanco, J., \& Gernjak, W. (2009). Decontamination and disinfection of water by solar photocatalysis: recent overview and trends. Catalysis Today, 147(1): 1-59.

Malato, S., Maldonado, M. I., Fernandez-Ibanez, P., Oller, I., Polo, I., \& Sanchez- Moreno, R. (2016). Decontamination and disinfection of water by solar photocatalysis: The pilot plants of the Plataforma Solar de Almeria. Materials Science in Semiconductor Processing, 42, 15-23.

Mondal, K. \& Sharma, A. (2014). Photocatalytic oxidation of pollutant dyes in wastewater by $\mathrm{TiO}_{2}$ and $\mathrm{ZnO}$ nanomaterials-A mini-review. Nanoscience \& Technology for Mankind; The Academy of Sciences India (NASI): Allahabad, India, 36-72.

Palmer, F. L., Eggins, B. R., \& Coleman, H. M. (2002). The effect of operational parameters on the photocatalytic degradation of humic acid. Journal of Photochemistry and Photobiology A: Chemistry, 148(1-3), 137-143.

Rajendran, S., Khan, M. M., Gracia, F., Qin, J., Gupta, V. K., \& Arumainathan, S. (2016). $\mathrm{Ce}^{3+}$-ion-induced visible-light photocatalytic degradation and electrochemical activity of $\mathrm{ZnO} / \mathrm{CeO}_{2}$ nanocomposite. Scientific Reports, 6, 31641. 
Rodrigues-Silva, C., Miranda, S. M., Lopes, F. V., Silva, M., Dezotti, M., Silva, A. M., Faria, J. L., Boaventura, R. A. R., Vilar, V. J. P. \& Pinto, E. (2017). Bacteria and fungi inactivation by photocatalysis under UVA irradiation: liquid and gas phase. Environmental Science and Pollution Research, 24(7), 6372-6381.

Seven, O., Dindar, B., Aydemir, S., Metin, D., Ozinel, M. A., \& Icli, S. (2004). Solar photocatalytic disinfection of a group of bacteria and fungi aqueous suspensions with $\mathrm{TiO}_{2}, \mathrm{ZnO}$ and Sahara desert dust. Journal of Photochemistry and Photobiology A: Chemistry, 165(1-3), 103-107

Umar, M., \& Aziz, H. A. (2013). Photocatalytic degradation of organic pollutants in water. Inorganic Pollutants-Monitoring, Risk and Treatment. 195-208. 